\title{
Respon Karakter Agronomi Cabai Rawit Lokal (Capsicum frutescens L.) terhadap Perlakuan Ekstrak Fitohormon Sebagai Upaya Domestikasi dalam Pemuliaan Tanaman
}

Angraeni Afrianti Una ${ }^{a}$,

a Fakultas Pertanian, Universitas Timor, Kefamenanu, TTU - NTT, Indonesia, email: angraeniuna2019@gmail.com

\section{Article Info}

\section{Article history:}

Received 22 Januari 2020

Received in revised form 28 Maret 2020 Accepted 26 April 2020

DOI:

https://doi.org/10.32938/sc.v5i02.973 Keywords:

Capsicum frutescens $\mathrm{L}$.

Domestikasi

Fitohormon

\begin{abstract}
Abstrak
Penelitian ini bertujuan untuk mengetahui respon karakter agronomi dari cabai rawit lokal Pulau Timor terhadap perlakuan konsentras dan frekuensi yang optimal fitohormon organik. Penelitian dilakukan di BBU (Balai Benih Unggul) Dinas Pertanian Kabupaten TTU Jl. Eltari Km 6 Kelurahan Sasi Kecamatan Kota Kefamenanu, Kabupaten Timor Tengah Utara pada bulan Juni sampai November 2019 dengan menggunakan Rancagan Acak Lengkap (RAL) pola faktorial 3x3 di ulang sebanyak 3 kali. Perlakuan pertama adalah konsentrasi bahan organik dengan 3 aras yaitu tanpa konsentrasi bahan organik, konsentrasi $45 \mathrm{ml} / \mathrm{L}$ air, konsentrasi $95 \mathrm{ml} / \mathrm{L}$ air dan perlakuan kedua adalah frekuensi waktu penyiraman yang terdiri dari 3 aras yaitu 1 minggu, 2 minggu, dan 3 minggu. Hasil penelitian menunjukkan bahwa tidak terjadi interaksi antara konsentrasi fitohormon dan waktu aplikasi pada setiap parameter pengamatan. Hasil penelitian menunjukkan bahwa perlakuan konsentrasi fitohormon $95 \mathrm{ml} / \mathrm{L}$ dengan penyiraman 1 kali dalam seminggu mampu meningkatkan hasil panen tanaman cabai rawit lokal Timor.
\end{abstract}

\section{Pendahuluan}

Cabai rawit (Capsicum Frustescens L.) merupakan salah satu tanaman hortikultura dari jenis sayuran yang memiliki buah kecil dengan rasa yang pedas. Cabai jenis ini dibudidayakan oleh para petani karena banyak dibutuhkan masyarakat, tidak hanya skala rumah tangga, tetapi juga digunakan dalam skala industri dan dieksport ke luar negeri. Tanaman ini mempunyai banyak manfaat terutama pada buahnya yaitu bumbu masak, bahan campuran industri makanan dan sebagai bahan kosmetik. Selain buahnya, bagian lain dari tanaman ini seperti batang, daun, dan akarnya juga dapat digunakan sebagai obat-obatan (Ashari, 1995). Kebutuhan akan cabai meningkat setiap tahunnya sejalan dengan meningkatnya jumlah penduduk dan berkembangnya industri yang membutuhkan bahan baku cabai. Meskipun kebutuhan akan cabai ini terus meningkat, namun produksi cabai di Indonesia masih rendah dan belum mencukupi seluruh kebutuhan, hal ini sering mengakibatkan langkanya cabai dipasaran dan fluktuasi harga yang tinggi. Oleh karena itu perlu dilakukan tindakan peningkatan produksi tanaman cabai ini melalui intensifikasi dan ekstensifikasi (Santika, 1999).

Produksi cabai rawit dikabupaten Timor Tengah Utara tercatat mengalami fluktuasi dari tahun 2013 hingga 2017 yaitu 24 t/ha; 25.70 t/ha; $22.30 \mathrm{t} / \mathrm{ha} ; 52 \mathrm{t} / \mathrm{ha}$; dan 43.70 t/ha (BPS Kab.TTU, 2018). Menurut Rukmana (2002), penurunan produksi dikarenakan petani mengalami gagal panen di akibatkan karena adanya beberapa kendala, terutama penggunaan varietas lokal, tingkat kesuburan tanah, dan serangan hama dan penyakit. Selain luas panennya yang rendah, cabai rawit harganya di pasaran sering kali lebih tinggi dari pada cabai jenis lainnya, sehingga cabai rawit merupakan salah satu sayuran unggulan yang bernilai ekonomi tinggi. Untuk meningkatkan pertumbuhan dan hasil tanaman cabai rawit maka diperlukan pemilihan varietas unggul sesuai kondisi lokal, tetapi perlu dilakukan juga menggunakan pemupukan, pengendalian hama dan penyebab penyakit secara simultan. Oleh sebab itu upaya untuk meningkatkan produktifitas cabai rawit lokal pulau Timor maka diperlukan untuk mengembangkan dengan cara memberikan zat fitohormon alami (hormon tumbuhan). Hormon tumbuhan atau fitohormon merupakan salah satu faktor yang mempengaruhi pertumbuhan dan perkembangan tanaman. Hormon tumbuhan dapat diartikan luas yakni sebagai suatu senyawa organik yang disintesis di salah satu bagian lain tanaman atau tumbuhan yang dapat mendorong maupun menghambat pertumbuhan. Hal ini dimaksudkan agar pertumbuhan cabai rawit lebih cepat dari biasanya.

Zat fitohormon yang digunakan adalah ekstrak daun kelor, air kelapa dan bawang merah. Menurut Krisnadi (2012) bahwa ekstrak daun kelor mengandung hormon yang dapat meningkatkan pertumbuhan tanaman yaitu sitokinin. Manfaat ekstrak daun kelor dapat digunakan dengan disemprot pada daun untuk mempercepat pertumbuhan tanaman. Salah satu fitorhormon yang di gunakan juga adalah air kelapa. Air kelapa merupakan salah satu bahan alami. Didalamnya terkandung hormon seperti sitokinin $5.8 \mathrm{mg} / \mathrm{l}$, auksin 0.07 $\mathrm{mg} / \mathrm{l}$ dan giberelin sedikit sekali serta senyawa lain yang dapat mensitimulasi perkecambahan dan pertumbuhan (Bey et al., 2006). Darlina et al., (2016) menyatakan bahwa penyiraman air kelapa $200 \mathrm{ml} / \mathrm{L}$ menghasilkan jumlah daun $30 \mathrm{HST}$, berat basah, dan berat kering terbaik pada pertumbuhan vegetative lada. Bahan lain yang mengandung fitohormon adalah tauge yang berasal dari kacang hijau. Fitohormon yang terkandung dalam tauge adalah auksin (Ulfa et al., 2013). Selanjutnya dikatakan bahwa untuk memperoleh fitohormon berupa auksin, sitokinin dan giberelin dapat diekstrak dari air kelapa dan biji jagung.

Hasil penelitian Ulfa et al., (2013) menunjukkkan bahwa penggunaan ekstrak biji jagung sebagai regulator pertumbuhan eksogen memberikan bibit kentang kualitas terbaik berdasarkan parameter persentase hidup kentang bibit $(100 \%)$, tinggi bibit $(15,87 \mathrm{~cm})$, jumlah daun $(9,40$ lembar) dan panjang akar $(13,39 \mathrm{~cm})$. Laporan penelitian Amaliah (2019) menyatakan bahwa penggunaan Zat Pengatur Tumbuh Alami (tauge, jagung muda, bonggol pisang, air kelapa, EM4, tetes tebu dan gula merah) memberikan pengaruh yang berbeda nyata terhadap pertumbuhan tinggi batang, jumlah daun dan memberikan pengaruh berbeda sangat nyata pada panjang akar tanaman vanili dengan konsentrasi 25 $\mathrm{ml} / \mathrm{L}$. dari uraian diatas maka penelitian ini bertujuan untuk mengetahui respon karakter agronomi dari cabai rawit lokal Pulau Timor dan mendapatkan konsentrasi dan frekuensi yang optimal terhadap pertumbuhan dan hasil cabai rawit lokal Pulau Timor.

\section{Metode}

Penelitian ini dilakukan di Balai Benih Unggul (BBU) Dinas Pertanian Kabupaten TTU J1. Eltari Km 6 Kelurahan Sasi Kecamatan Kota Kefamenanu, Kabupaten Timor Tengah Utara, Provinsi Nusa Tenggara Timur pada bulan Juni sampai November 2019. Penelitian ini menggunakan Rancagan Acak Lengkap (RAL) dengan pola faktorial 3x3 di ulang sebanyak 3 kali. Perlakuan pertama adalah konsentrasi bahan alami fitohormon (U) dengan 3 aras yaitu tanpa konsentrasi (U0), konsentrasi $45 \mathrm{ml} / \mathrm{L}$ air (U1), konsentrasi $95 \mathrm{ml} / \mathrm{L}$ air (U2) dan perlakuan kedua adalah frekuensi waktu penyiraman (T) yang terdiri dari 3 aras yaitu 1 minggu sekali (T1), 2 minggu sekali (T2), dan 3 minggu sekali (T3), dengan kombinasi perlakuannya: $\mathrm{U}_{0} \mathrm{~T}_{1}, \mathrm{U}_{1} \mathrm{~T}_{1}, \mathrm{U}_{2} \mathrm{~T}_{1}, \mathrm{U}_{0} \mathrm{~T}_{2}, \mathrm{U}_{1} \mathrm{~T}_{2}$, $\mathrm{U}_{2} \mathrm{~T}_{2}, \mathrm{U}_{0} \mathrm{~T}_{3}, \mathrm{U}_{1} \mathrm{~T}_{3}, \mathrm{U}_{2} \mathrm{~T}_{3}$. Sehingga terdapat 27 unit percobaan. Semua data yang diperoleh ditabulasikan kemudian dianalisa dengan menggunakan sidik ragam (Anova) Rancangan Acak Lengkap (RAL), selanjutnya untuk mengetahui pengaruh perlakuan yang diberikan, rata-rata perlakuan diuji lanjut menggunakan Duncan Multiple RangeTest (DMRT) pada jenjang $5 \%$ sesuai petunjuk Gomez dan Gomez (1995).

Analisis data menggunakan program SAS 9. Bahan yang digunakan sebagai fitohormon dalam penelitian ini adalah jagung muda sebanyak $1 \mathrm{~kg}$, tauge kacang hijau $1 \mathrm{~kg}$ dan air kelapa muda sebanyak $1 \mathrm{~L}$. Jagung muda dan tauge dicampur menjadi satu kemudian diblender sampai halus. Kemudian dicampurkan dengan air kelapa muda, gula dan EM4. Setelah itu bahan-bahan tersebut difermentasikan selama 14 hari lalu disaring untuk memisahkan cairan dan padatan. Hasil ektrak siap digunakan sesuai dengan perlakuan. Parameter yang diamati dalam penelitian ini, sebagai berikut: tinggi tanaman, diameter batang, jumlah buah per tanaman, panjang buah per tanaman, diameter buah per tanaman, dan bobot buah.

\section{Hasil dan Pembahasan \\ Tinggi Tanaman $(\mathbf{c m})$}

Hasil sidik ragam (anova) menunjukkan bahwa tidak terjadi interaksi antara perlakuan konsentrasi fitohormon dan waktu aplikasi terhadap tinggi tanaman cabai rawit lokal pada semua waktu pengamatan. Hasil uji lanjut DMRT menunjukkan bahwa baik perlakuan konsentrasi maupun waktu aplikasi fitohormon tidak berbeda nyata (Tabel 1).

Waktu pengamatan 14HST, 21HST dan 28HST perlakuan tanpa pemberian fitohormon memberikan vegetasi tanaman tertinggi dan terendah diberikan oleh $45 \mathrm{ml} / \mathrm{L}$. Hal ini dapat di jelaskan dalam penelitian Prianti (2017), bahwa Adanya pengaruh perkecambahan dan pertumbuhan tanaman Cabai rawit (Capsicum frutescens) dengan menggunakan fitohormon alami ekstrak bawang merah dan air kelapa. Namun, fitohormon alami lebih bagus menggunakan air kelapa yang konsentrasi $50 \%$ pada pertumbuhan tinggi tanaman, lebar daun tanaman, jumlah daun dan warna daun. Sedangkan untuk pertumbuhan panjang daun tanaman lebih bagus menggunakan ekstrak bawang merah yang konsentrasi $30 \%$.

\section{Diameter Batang (mm)}

Hasil sidik ragam (anova) menunjukkan bahwa tidak terjadi interaksi antara perlakuan konsentrasi fitohormon dan waktu aplikasi terhadap diameter batang cabai rawit lokal pada semua waktu pengamatan. Hasil uji lanjut DMRT menunjukkan bahwa baik perlakuan konsentrasi maupun waktu aplikasi fitohormon tidak berbeda nyata (Tabel 2). Perlakuan konsentrasi fitohormon 95 $\mathrm{ml} / \mathrm{L}$ memberikan diameter batang terbesar pada pengamatan 14HST, 21HST 
dan 28HST.Namun pada akhir pengamatan yaitu 28HST perlakuan tanpa pemberian fitohormon juga memberikan diameter batang terbesar dan terendah diberikan oleh $45 \mathrm{ml} / \mathrm{L}$ pada pengamatan 14HST, 21HST dan 28HST. Hal ini dapat dikatakan Wattimena (1987) hormon Auksin yg di kombinasikan dengan Giberelin dapat memacu pertumbuhan jaringan pembuluh dan mendorong pembelahan sel pada kambium pembuluh sehingga mendukung pertumbuhan diameter batang. Menurut Yong et al,. (2009) air kelapa mengandung berbagaijenis sitokinin alami yang dapat meningkatkan pembelahan sel dan merangsang pertumbuhan.

Tabel 1. Tinggi Tanaman

\begin{tabular}{|c|c|c|c|c|c|}
\hline \multirow{2}{*}{$\begin{array}{l}\text { Waktu Pengamatan } \\
\text { (HST) }\end{array}$} & \multirow{2}{*}{$\begin{array}{l}\text { Waktu } \\
\text { Aplikasi }\end{array}$} & \multicolumn{3}{|c|}{ Konsetrasi Fitohormon (ml/L) } & \multirow{2}{*}{ Rerata } \\
\hline & & Tanpa & 45 & 95 & \\
\hline \multirow{4}{*}{14 HST } & 1 Minggu & 6,50 & 6,07 & 6,83 & $6,47 \mathrm{a}$ \\
\hline & 2 Minggu & 6,50 & 6,67 & 6,57 & $6,58 \mathrm{a}$ \\
\hline & 3 Minggu & 6,67 & 6,53 & 6,23 & $6,48 \mathrm{a}$ \\
\hline & Rerata & $6,56 \mathrm{a}$ & $6,42 \mathrm{a}$ & $6,54 \mathrm{a}$ & $(-)$ \\
\hline \multirow{4}{*}{$21 \mathrm{HST}$} & 1 Minggu & 7,50 & 7,50 & 7,67 & $7,56 \mathrm{a}$ \\
\hline & 2 Minggu & 8,17 & 7,13 & 7,33 & $7,54 \mathrm{a}$ \\
\hline & 3 Minggu & 7,33 & 7,33 & 7,50 & $7,39 \mathrm{a}$ \\
\hline & Rerata & $7,67 \mathrm{a}$ & $7,32 \mathrm{a}$ & $7,50 \mathrm{a}$ & $(-)$ \\
\hline \multirow{4}{*}{$28 \mathrm{HST}$} & 1 Minggu & 9,17 & 8,33 & 8,33 & $8,61 \mathrm{a}$ \\
\hline & 2 Minggu & 9,67 & 8,33 & 9,17 & $9,06 \mathrm{a}$ \\
\hline & 3 Minggu & 9,67 & 9,00 & 8,33 & $9,00 \mathrm{a}$ \\
\hline & Rerata & $9,50 \mathrm{a}$ & $8,56 \mathrm{a}$ & $8,61 \mathrm{a}$ & $(-)$ \\
\hline
\end{tabular}

Keterangan: Angka pada baris dan kolom diikuti huruf yang sama menunjukkan tidak berbeda nyata pada tingkat signifikan( $\alpha$ ) $5 \%$, menurut uji DMRT (-) tidak terjadi interaksi antar faktor.

Tabel 2. Diameter Batang

\begin{tabular}{|c|c|c|c|c|c|}
\hline \multirow{2}{*}{$\begin{array}{l}\text { Waktu Pengamatan } \\
\text { (HST) }\end{array}$} & \multirow{2}{*}{$\begin{array}{l}\text { Waktu } \\
\text { Aplikasi }\end{array}$} & \multicolumn{3}{|c|}{ Konsetrasi Fitohormon $(\mathrm{ml} / \mathrm{L})$} & \multirow{2}{*}{ Rerata } \\
\hline & & Tanpa & 45 & 95 & \\
\hline \multirow{4}{*}{$14 \mathrm{HST}$} & 1 Minggu & 0,30 & 0,27 & 0,30 & $0,29 \mathrm{a}$ \\
\hline & 2 Minggu & 0,30 & 0,30 & 0,30 & $0,30 \mathrm{a}$ \\
\hline & 3 Minggu & 0,27 & 0,30 & 0,30 & $0,29 \mathrm{a}$ \\
\hline & Rerata & $0,29 \mathrm{a}$ & $0,29 \mathrm{a}$ & $0,30 \mathrm{a}$ & $(-)$ \\
\hline \multirow{4}{*}{$21 \mathrm{HST}$} & 1 Minggu & 0,33 & 0,33 & 0,40 & $0,36 \mathrm{a}$ \\
\hline & 2 Minggu & 0,37 & 0,33 & 0,33 & $0,34 \mathrm{a}$ \\
\hline & 3 Minggu & 0,33 & 0,30 & 0,37 & $0,33 \mathrm{a}$ \\
\hline & Rerata & $0,34 \mathrm{a}$ & $0,32 \mathrm{a}$ & $0,37 \mathrm{a}$ & $(-)$ \\
\hline \multirow{4}{*}{$28 \mathrm{HST}$} & 1 Minggu & 0,40 & 0,37 & 0,40 & $0,39 \mathrm{a}$ \\
\hline & 2 Minggu & 0,43 & 0,37 & 0,47 & $0,42 \mathrm{a}$ \\
\hline & 3 Minggu & 0,43 & 0,43 & 0,40 & $0,42 \mathrm{a}$ \\
\hline & Rerata & $0,42 \mathrm{a}$ & $0,39 \mathrm{a}$ & $0,42 \mathrm{a}$ & $(-)$ \\
\hline
\end{tabular}

Keterangan: Angka pada baris dan kolom diikuti huruf yang sama menunjukkan tidak berbeda nyata pada tingkat signifikan( $\alpha$ ) 5\%, menurut uji DMRT. (-): Tidak terjadi interaksi antar faktor.

\section{Jumlah Buah Per Tanaman}

Hasil sidik ragam (anova) menunjukkan bahwa tidak terjadi interaksi antara perlakuan konsentrasi fitohormon dan waktu aplikasi terhadap jumlah buah per tanaman cabai rawit lokal pada semua waktu panen. Hasil uji lanjut DMRT menunjukkan bahwa baik perlakuan konsentrasi maupun waktu aplikasi fitohormon tidak berbeda nyata kecuali pada waktu panen panen 1 pada aras perlakuan konsentrasi berbeda nyata denga naras perlakuan tanpa konsentrasi menghasilkan jumlah buah per tanaman lebih banyak yang berbeda nyata dengan perlakuan lainnya (Tabel 3). Perlakuan tanpa pemberian fitohormon memberikan jumlah buah terbanyak dibandingkan kedua perlakuan konsentras fitohormon lainnya. Hal ini dijelaskan bahwa pengaruh dari hormon Endogen yang terdapat pada tanaman cabai yang memungkinkan penyerapan hormon untuk pertumbuhan tanamana cabai rawit itu sendiri.

\section{Panjang Buah}

Hasil sidik ragam (anova) menunjukkan bahwa tidak terjadi interaksi antara perlakuan konsentrasi fitohormon dan waktu aplikasi terhadap panjang buah cabai rawit lokal pada saat pengamatan. Hasil uji lanjut DMRT menunjukkan bahwa perlakuan konsentrasi tidak berbeda nyata tetapi waktu aplikasi fitohormon berbeda nyata dengan waktu aplikasi aplikasi 3 minggu sekali menghasilkan panjang buah paling panjang dan berbeda nyata dengan waktu aplikasi 1 minggu sekali (Tabel 4). Perlakuan konsentrasi fitohormon 95 $\mathrm{ml} / \mathrm{L}$ menunjukkan panjang buah terpanjang. Dibanding perlakuan konsentrasi fitohormon $45 \mathrm{ml} / \mathrm{L}$ yang memberikan panjang buah terendah. Hal ini dapat dibandingkan dengan penelitian Lelang et al., (2018), bahwa panjang buah tanaman cabai rawit lokal berkisar antara 0,73 sampai 0,78 . Hal ini dapat di simpulkan bahwa perlakuan fitohormon mampu meningkatkan hasil tanaman karena kandungan unsur hara didalam mampu dimanfaatkan oleh tanaman dengan baik. Selanjutnya dijelaskan oleh penelitian Sumisari dan Priadi (2003), tanaman memerlukan konsentrasi auksin yang sesuai untuk pertumbuhannya. Kusumo (1990) menyatakan bahwa zat pengatur tumbuh efektif dalam jumlah tertentu, konsentrasi yang terlalu rendah atau tinggi menyebabkan tidak efektifnya kerja zat pengatur tumbuh. Sedangkan menurut Gholami et al., (2009) melaporkan bahwa benih tanaman jagung yang diinokulasi dengan Pseudomonas, Azospirilium dan Azotobacter meningkatkan pertumbuhan dan produktivitas jagung melalui sintesis fitohormon, meningkatkan serapan hara sekitar akar, mendukung penyerapan hara melalui penurunan tingkat keracunan logam berat dan melawan patogen. Tanaman yang diinokulasi PGPR juga menunjukkan peningkatan luas daun, bobot segar tanaman serta bobot kering biji terutama bobot 100 biji dan jumlah biji pertongkol.

Tabel 3. Jumlah Buah Tanaman

\begin{tabular}{|c|c|c|c|c|c|}
\hline \multirow{2}{*}{$\begin{array}{l}\text { Waktu Pengamatan } \\
\text { (HST) }\end{array}$} & \multirow{2}{*}{$\begin{array}{l}\text { Waktu } \\
\text { Aplikasi }\end{array}$} & \multicolumn{3}{|c|}{ Konsetrasi Fitohormon (ml/L) } & \multirow[b]{2}{*}{ Rerata } \\
\hline & & Tanpa & 45 & 95 & \\
\hline \multirow{4}{*}{ Panen 1} & 1 Minggu & 10,33 & 10,33 & 3,33 & $8,00 \mathrm{a}$ \\
\hline & 2 Minggu & 12,00 & 3,33 & 3,67 & $6,33 \mathrm{a}$ \\
\hline & 3 Minggu & 17,67 & 3,33 & 2,67 & $7,89 \mathrm{a}$ \\
\hline & Rerata & $13,33 \mathrm{a}$ & $5,67 \mathrm{~b}$ & $3,22 \mathrm{~b}$ & $(-)$ \\
\hline \multirow{4}{*}{ Panen 2} & 1 Minggu & 22,33 & 26,33 & 21,33 & $23,33 \mathrm{a}$ \\
\hline & 2 Minggu & 27,67 & 18,00 & 17,33 & $21,00 \mathrm{a}$ \\
\hline & 3 Minggu & 26,33 & 20,67 & 23,00 & $23,33 \mathrm{a}$ \\
\hline & Rerata & $25,44 \mathrm{a}$ & $21,67 \mathrm{a}$ & $20,56 \mathrm{a}$ & $(-)$ \\
\hline \multirow{4}{*}{ Panen 3} & 1 Minggu & 32,00 & 47,67 & 49,00 & $42,89 \mathrm{a}$ \\
\hline & 2 Minggu & 37,67 & 45,33 & 50,33 & $44,44 \mathrm{a}$ \\
\hline & 3 Minggu & 36,67 & 44,33 & 46,67 & $42,56 \mathrm{a}$ \\
\hline & Rerata & $35,44 \mathrm{~b}$ & $45,78 \mathrm{a}$ & $48,67 \mathrm{a}$ & $(-)$ \\
\hline \multirow{4}{*}{ Jumlah Total } & 1 Minggu & 64.67 & 84.33 & 73.67 & $74.22 \mathrm{a}$ \\
\hline & 2 Minggu & 77.33 & 66.67 & 71.33 & $71.78 \mathrm{a}$ \\
\hline & 3 Minggu & 80.67 & 68.33 & 72.33 & $73.78 \mathrm{a}$ \\
\hline & Rerata & $74.22 \mathrm{a}$ & $73.11 \mathrm{a}$ & $72.44 \mathrm{a}$ & $(-)$ \\
\hline
\end{tabular}

Keterangan: Angka pada baris dan kolom diikuti huruf yang sama menunjukkan tidak berbeda nyata pada tingkat signifikan( $\alpha$ ) 5\%, menurut uji DMRT. (-): Tidak terjadi interaksi antar faktor.

Tabel 4. Panjang Buah

\begin{tabular}{ccccc}
\hline \multirow{2}{*}{ Waktu Aplikasi } & \multicolumn{3}{c}{ Konsetrasi Fitohormon $(\mathrm{ml} / \mathrm{L})$} & \multirow{2}{*}{ Rerata } \\
\cline { 2 - 4 } & Tanpa & 45 & 95 & \\
\hline 1 Minggu & 1.51 & 1.47 & 1.56 & $1.52 \mathrm{~b}$ \\
2 Minggu & 1.61 & 1.50 & 1.66 & $1.59 \mathrm{ab}$ \\
3 Minggu & 1.66 & 1.64 & 1.70 & $1.67 \mathrm{a}$ \\
\hline Rerata & $1.59 \mathrm{a}$ & $1.54 \mathrm{a}$ & $1.64 \mathrm{a}$ & $(-)$ \\
\hline
\end{tabular}

Keterangan: Angka pada baris dan kolom diikuti huruf yang sama menunjukkan tidak berbeda nyata pada tingkat signifikan( $\alpha$ ) $5 \%$, menurut uji DMRT. (-): Tidak terjadi interaksi antar faktor.

\section{Diameter Buah (cm)}

Hasil sidik ragam (anova) menunjukkan bahwa tidak terjadi interaksi antara perlakuan konsentrasi fitohormon dan waktu aplikasi terhadap diameter buah cabai rawit lokal pada saat pengamatan. Hasil uji lanjut DMRT menunjukkan bahwa perlakuan konsentrasi maupun waktu aplikasi fitohormon tidak berpengaruh (Tabel 5). Hasil penelitian menunjukkan bahwa ukuran diameter buah lebih besar dengan memberikan perlakuan konsentrasi dan waktu aplikasi fitohormon jika dibandingkan dengan penelitian Lelang et.al., (2018) bahwa rata-rata diameter buah tanaman cabai rawit lokal berkisar antara 0,36-0,38 $\mathrm{cm}$. dari data tersebut dapat disimpulkan bahwa pemberian konsentrasi fitohormon mampu meningkatkan diameter buah tanaman. Dapat dijelaskan secara nyata dalam penelitian Djamhari (2010), zat pengatur tumbuh eksogen yang diaplikasikan pada tanaman berfungsi untuk memacu pembentukan fitohormon. Hormon dapat mendorong suatu aktivitas biokimia.Fitohormon sebagai senyawa organik yang bekerja aktif dalam jumlah sedikit biasanya ditransformasikan ke seluruh bagian tanaman sehingga dapat memengaruhi pertumbuhan atau proses-proses fisiologi tanaman. Hal ini didukung oleh pendapat Anwaruddinet al., (1996) yang menyatakan bahwa penggunaan hormon tumbuh eksogen hanya dapat berpengaruh terhadap fisiologi tanaman jika kandungan hormon di dalam jaringan tanaman belum mencukupi sehingga menjadi faktor pembatas.

Tabel 5. Diameter Buah

\begin{tabular}{ccccc}
\hline Waktu & \multicolumn{3}{c}{ Konsetrasi Fitohormon $(\mathrm{ml} / \mathrm{L})$} & \multirow{2}{*}{ Rerata } \\
\cline { 2 - 4 } Aplikasi & Tanpa & 45 & 95 & \\
\hline 1 Minggu & 0.39 & 0.37 & 0.40 & $0.39 \mathrm{a}$ \\
2 Minggu & 0.40 & 0.39 & 0.39 & $0.40 \mathrm{a}$ \\
3 Minggu & 0.40 & 0.41 & 0.40 & $0.40 \mathrm{a}$ \\
\hline Rerata & $0.40 \mathrm{a}$ & $0.39 \mathrm{a}$ & $0.40 \mathrm{a}$ & $(-)$ \\
\hline
\end{tabular}

Keterangan: Angka pada baris dan kolom diikuti huruf yang sama menunjukkan tidak berbeda nyata pada tingkat signifikan( $\alpha$ ) $5 \%$, menurut uji DMRT. (-): Tidak terjadi interaksi antar faktor.

\section{Bobot Buah}

Hasil sidik ragam (anova) menunjukkan bahwa tidak terjadi interaksi antara perlakuan konsentrasi fitohormon dan waktu aplikasi terhadap bobot buah cabai rawit lokal pada semua waktu pengamatan. Hasil uji lanjut DMRT menunjukkan bahwa perlakuan konsentrasi tidak berbeda nyata pada waktu pengamatan panen 1 dan panen 2 tetapi pada saat panen 3 dan total panen berbeda nyata dengan aras perlakuan konsentrasi $95 \mathrm{ml} / \mathrm{L}$ memberikan bobot buah paling tetapi waktu aplikasi fitohormon berbeda nyata dengan waktu aplikasi aplikasi 3 minggu sekali menghasilkan panjang buah paling panjang dan berbeda nyata dengan waktu aplikasi 1 minggu sekali (Tabel 6). Hasil 
penelitian menunjukkan bahwa total bobot buah lebih berat dengan memberikan perlakuan konsentrasi dan waktu aplikasi fitohormon jika dibandingkan dengan penelitian Lelang et.al., (2018) bahwa rata-rata bobot buah tanaman cabai rawit lokal berkisar antara 9,47-15,0. Selanjutnya dijelaskan dalam penelitian Agustina (2013), bahwa Perlakuan konsentrasi ZPT 1,5 $\mathrm{ml} / \mathrm{L}$ mampu meningkatkan bobot biji per petak, bobot biji per rumpun, bobot 100 butir dan indeks panen.

\section{Tabel 6. Bobot Buah}

\begin{tabular}{|c|c|c|c|c|c|}
\hline \multirow{2}{*}{$\begin{array}{c}\text { Waktu } \\
\text { Pengamatan } \\
\text { (HST) }\end{array}$} & \multirow{2}{*}{$\begin{array}{l}\text { Waktu } \\
\text { Aplikasi }\end{array}$} & \multicolumn{3}{|c|}{ Konsetrasi Fitohormon (ml/L) } & \multirow{2}{*}{ Rerata } \\
\hline & & Tanpa & 45 & 95 & \\
\hline \multirow{4}{*}{ Panen 1} & 1 Minggu & 0,76 & 0,90 & 0,69 & $0,79 \mathrm{a}$ \\
\hline & 2 Minggu & 0,87 & 0,50 & 0,82 & $0,73 \mathrm{a}$ \\
\hline & 3 Minggu & 0,73 & 0,83 & 0,83 & $0,80 \mathrm{a}$ \\
\hline & Rerata & $0,79 \mathrm{a}$ & $0,75 \mathrm{a}$ & $0,78 \mathrm{a}$ & $(-)$ \\
\hline \multirow{4}{*}{ Panen 2} & 1 Minggu & 5,32 & 4,48 & 5,20 & $5,00 \mathrm{a}$ \\
\hline & 2 Minggu & 4,55 & 4,05 & 3,32 & $3,97 \mathrm{~b}$ \\
\hline & 3 Minggu & 4,74 & 6,10 & 5,55 & $5,46 \mathrm{a}$ \\
\hline & Rerata & $4,87 \mathrm{a}$ & $4,88 \mathrm{a}$ & $4,69 \mathrm{a}$ & $(-)$ \\
\hline \multirow{4}{*}{ Panen 3} & 1 Minggu & 6,66 & 10,55 & 11,16 & $9,46 \mathrm{a}$ \\
\hline & 2 Minggu & 8,60 & 10,09 & 10,26 & 9,65 a \\
\hline & 3 Minggu & 7,78 & 8,81 & 10,01 & $8,87 \mathrm{a}$ \\
\hline & Rerata & $7,68 \mathrm{~b}$ & $9,82 \mathrm{a}$ & $10,48 \mathrm{a}$ & $(-)$ \\
\hline \multirow{4}{*}{ Berat Total } & 1 Minggu & 12.74 & 15.93 & 17.05 & $15.24 \mathrm{a}$ \\
\hline & 2 Minggu & 14.02 & 14.64 & 14.39 & $14.35 \mathrm{a}$ \\
\hline & 3 Minggu & 13.24 & 15.74 & 16.40 & $15.13 \mathrm{a}$ \\
\hline & Rerata & $13.34 \mathrm{~b}$ & $15.44 \mathrm{a}$ & $15.95 \mathrm{a}$ & $(-)$ \\
\hline
\end{tabular}

Keterangan: Angka pada baris dan kolom diikuti huruf yang sama menunjukkan tidak berbeda nyata pada tingkat signifikan( $\alpha$ ) $5 \%$, menurut uji DMRT. (-): Tidak terjadi interaksi antar faktor.

\section{Simpulan}

Hasil penelitian menunjukkan bahwa tidak terjadi interaksi antara konsentrasi fitohormon dan waktu apllikasi pada setiap parameter pengamatan. Aras perlakuan perlakuan fitohormon $95 \mathrm{ml} / \mathrm{L}$ dan aras perlakuan frekuensi penyiraman 1 kali dalam seminggu mampu meningkatkan hasil panen tanaman cabai rawit lokal pulau Timor.

\section{Pustaka}

Agustina. 2013. Zat Pengatur Tumbuh Dan Hormon Pada Tumbuhan.https://agustina.wordpress.com/2013/10/06/hormon-padatumbuhan/.[12April 2017].

Anwaruddin, M.J., N. L. P. Indrayani, S. Hardianti, dan E. Mansyah. 1996 perkecambahan dan pertumbuhan biji manggis. Jurnal Hortikultura 6:1-5

Ashari ,S1995, Hortikultura. Aspek Budidaya. UI press. Jakarta

AmaliahAyu Wilda, 2019, Aplikasi Zat Pengatur Tumbuh Alami Untuk Aklimatisasi Tanaman Vanili (Vanilla planifolia A.), Skripsi, Politeknik Negeri Jember.

Bey, Y,.W Syafii dan Sutrisna. 2006. Pengaruh Pemberian Gibrelin Dan Air Kelapa Terhadap Pertumbuhan Anggrek Bulan. Bulan . Riau. Riau

Djamhari , S. 2010. Memecah dormansi rimpang temulawak (Curcuma xanthrizza R.) menggunakan larutan atonik dan stimulasi perakaran dengan aplikasi auksin. Jurnal Sains dan Teknologi Indonesia 12: 66-70.

Darlina, Hasanuddin, Hafnati Rahmatan, 2016, Pengaruh Penyiraman Air Kelapa (Cocos nucifera L.) Terhadap Pertumbuhan Vegetatif Lada (Piper nigrum L.), Jurnal Ilmiah Mahasiswa Pendidikan Biologi, Volume 1, Issue 1

Gomez, K.A., Gomez, A.A. 2010. Prosedur Statistik Untuk Penelitian Pertanian. Edisi ke 2. UI Press: Jakarta.

Gholami, A.,S. Shahsavani , and S. Nezarat. 2009. The effect of plant growth promoting rhizobacteria $(P G P R)$ on germanatio, seedling growth and yield of maize. Word Academy of science, Engineering and Technologi 49:19-24

Krisnadi ,A. D. 2015. Kelor Super Nutrisi . Edisi Revisi. Pusat Informasi dan Pengembangan Tanaman Kelor Indonesia , Lembaga Swadaya Masyarakat-Media Peduli Lingkungan (LSM-MEPELING). Kunduran , Blora

Maria Afnita Lelang, Syprianus Ceunfin \& Adrianus Lelang, 2018.Karakteristik Morfologi Dan Komponen Hasil Cabai Rawit (Capsicum frutescens L.) Asal Pulau Timor. Savana Cendana 4(1).

Rukmana RH. 2002 .Usaha Tani Cabai Rawit .Kanisius ,Yogyakarta.

Santika, A.,1999. Agribisnis Tanaman Cabai. Penebar Swadaya, Jakarta.

Sumisari, N dan D. Priadi. 2003. Pertumbuhan stek cabang sungkai (peronemacanescens Jack) pada berbagai konsentrasi zat pengatur tumbuh (GA3) dalam media cair. Jurnal Natur Indonesia. Majalah Ilmiah Lembaga Penelitian Universitas Riau volume 6 (1):1-2
Yong, J.W.H., Liya Ge, Yan F.N., dan Swee N. T. 2009. The chemical compotition and biological properties of coconut ( Cocos nucifera $\mathrm{L}$.) water. Molecules 14: 5244-5164

Wattimena, G.A 1987. Zat Pengatur Tumbuh. PAU Bioteknologi,IPB. Bogor.

Ulfa Fachirah, Enny Lisan Sengin, Baharuddin Baharuddin, Syatrianti Andi Syaiful, Nadira R. Sennang, Rafiuddin Rafiuddin, Nurfaida Nurfaida, Ifayanti Ifayanti, 2013, Potential of Plant Extracts as Growth Exogenous Regulators of Potato Seeds, International Journal of Agriculture Systems (IJAS), Volume 1 Issue 2 